\title{
Creationist Teaching in School Science: A UK Perspective
}

\author{
James David Williams
}

Published online: 20 November 2007

(C) Springer Science + Business Media, LLC 2007

\begin{abstract}
The creation/evolution controversy in UK schools made headlines in the national press, on TV, and radio in 2002. Claims were made that creationism was being taught in schools. This article looks at the impact this controversy had on the UK government and how creationism is trying to gain ground in UK state schools by introducing students to Intelligent Design through promotional DVDs. Student attitude surveys eliciting views toward science and religion are examined. Concern is also expressed at how the teaching of evolution through standard textbooks may not deliver a persuasive case for evolutionary theory. The article concludes with a number of implications for researchers, teachers, and schools.
\end{abstract}

Keywords Creationism · Intelligent design .

School science $\cdot$ Teaching

\section{Introduction}

A documented and verifiable case of creationist teaching in UK schools is rare. In the past 5 years or so, creationist movement attempts to infiltrate UK science teaching have gained considerable attention in the national media (Allgaier and Holliman 2006). In 2002, it was reported that a UK state funded educational academy ${ }^{1}$, The Emmanuel College, Gateshead, was linked to creationist teaching in science lessons (Branigan 2002). The story ignited a row, which led to questions from MPs in the House of Commons, challenging creationism and its place, if any, in the school science curriculum. In reply the then Prime Minister, Tony Blair, reported that claims of creationist teaching were "somewhat exaggerated" (Hoggart 2002). What concerned commentators and observers then was his lack of a definitive condemnation of creationism being included in science teaching. Since 2002 the issue has been periodically reported, with a resurgence of stories in 2006 when it was revealed that a reference to creationism was included in a national, public science examination syllabus for 16-year-olds (Paton 2006a, b). That reference has since been removed. In September 2006, a new organization, Truth in Science, distributed promotional DVDs to all state secondary schools challenging Darwinian evolution and supporting intelligent design, with a call for these to be used to "teach the controversy" in science lessons (http:// www.truthinscience.org.uk/ (accessed May 2007)).
J. D. Williams $(\bowtie)$

Sussex School of Education,

University of Sussex Falmer campus,

Brighton BN1 9QQ, UK

e-mail: James.Williams@sussex.ac.uk

\footnotetext{
${ }^{1}$ Academies are a UK government initiative to link private finance to state-financed education resulting in a policy of regenerating and replacing failing schools in inner cities. Private sponsors contribute $£ 2$ million pounds sterling to the cost of setting up an academy representing approximately a $10 \%$ contribution to the total cost of a new school building. The sponsors have a pivotal role in the governance of the school and a degree of control over the curriculum taught.
} 


\section{Curriculum Requirements for Teaching Evolution}

In 1988, a national curriculum was introduced to schools in England and $\mathrm{Wales}^{2}$ for the first time. It covered the statutory subject content that should be taught in core subjects, such as English, mathematics, and science as well as prescribing the content for a range of other subjects such as technology, humanities, the arts, and physical education. The science national curriculum is split into four major "attainment targets", labeled Sc1-4 for convenience. Sc1 deals with the practical, investigative nature of science; Sc2 covers biology; Sc3 chemistry, and Sc4 physics and astronomy. Since 1988, a number of revisions to the curriculum have been implemented. The latest happened in September 2006, with a reduction in the prescribed factual content across Sc2-4 and a move toward teaching the process of science, termed "how science works". There is some evidence to suggest, however, that science teachers' own understanding of the process or nature of science and the status of theories, laws, and facts in science is not as fully developed as it needs to be to implement this fundamental shift in focus (Williams 2006, 2008).

What should be taught in school science, from 2002 to September 2006, remained constant. The requirements for teaching evolution in biology were clearly spelled out in Sc2:

\section{Pupils should be taught:}

- that the fossil record is evidence for evolution

- how variation and selection may lead to evolution or to extinction"(DfEE 1999:40)

Another aspect of science, how scientific ideas have changed over time and how scientific controversies arise, was also required in the national curriculum as part of $\mathrm{Sc} 1$. To illustrate what was meant by this, Darwin's theory of evolution was used as an example, entirely separate from the teaching of evolution as required in the biology section:

Pupils should be taught... how scientific controversies can arise from different ways of interpreting empirical evidence (for example, Darwin's theory of evolution)" (DfEE 1999:37)

The interpretation of this to include any supposed controversy over the fact of evolution, or controversy between scientists over the introduction of an alternative theory to evolution, e.g., "scientific creationism" or "intelligent design", was an interpretation conveniently used by the creationist movements rather than those who constructed the original curriculum requirements. More recently, the UK pressure organization Truth in Science is

\footnotetext{
$\overline{2}$ Scotland has a different education system, curriculum, and examination structure.
}

using the "controversy" context as a justification for including intelligent design in science classes.

\section{Creationism Teaching at Emmanuel College}

Reports of creationist teaching at The Emmanuel College in 2002 signaled the first high-profile case to be investigated publicly. The Emmanuel Schools Foundation (ESF), formerly The Vary Foundation, disputes that creationism has been taught as an official part of its science curriculum (http://www.emmanuelctc.org.uk/thefoundation/history/ accessed 24th October 2007). The ESF currently operates three academies in the North East of England, Emmanuel College Gateshead, The King's Academy in Middlesbrough, and Trinity Academy in Doncaster. The ESF was set up by a businessman, Sir Peter Vardy. All three are characterized as independent schools ${ }^{3}$ with a religious character and an ethos based on Christian faith and biblical principles. The schools are not classified as "faith schools" as they do not operate a selection policy for a proportion of their students from one particular faith. Academies are sponsored and governed independently, but are mostly state-funded and, consequently, are counted as state schools. There are currently over 60 academies operating in the UK, sponsored by a range of organizations, including businesses, banks, educational foundations, and universities. The government plans to open 200 academies by 2010 . They have an official government classification as "City Technology Colleges" that specialize in one or more areas of the curriculum, e.g., Emmanuel College has been designated as a specialist school for teaching technology and business and enterprise. None of the ESF schools operate a religious test for admission.

Sir Peter Vardy, founder of the ESF and academy sponsor, initially admitted creationist teaching was con-

\footnotetext{
${ }^{3}$ The official classification of schools in the UK is complicated. Essentially there are three types of schools, private schools such as Eton and Harrow that are fee paying, who do not receive government funding and have almost complete autonomy over their curriculum; independent schools, such as city technology colleges and academies, which are private/public partnerships where independence comes from freedom to vary the state curriculum - they are not allowed to charge fees; and state-maintained schools, which are funded by central government and must deliver the statutory national curriculum in full. Confusion often arises as many private schools label themselves as "independent schools". A further category of state-maintained schools is Faith schools, set up and run by a recognized denominational faith, e.g., the Catholic Church. These schools are allowed to select a small proportion of their intake on a faith basis. All state-funded schools must offer, by law, religious education and should provide whole school assemblies that have a "broadly Christian" message. In all, there are some 4,500 state secondary schools in England and Wales. Private schools account for the education of approximately $7 \%$ of all secondary age (11-18) pupils.
} 
ducted alongside evolution theory in science lessons at Emmanuel College in a BBC radio interview in 2003 (Vardy 2003). He has since retreated from this position claiming in another BBC interview in 2006 (Vardy 2006) that his earlier comments had been misinterpreted. He states openly that he is a believer in a creator God; he is not, he says, a biblical, 6-day creation literalist. Creationist teaching, he claims, does not happen in science lessons at the Foundation's schools. In his 2006 BBC radio interview (Vardy 2006), Vardy also stated that if teachers are asked their beliefs by students, then it would be perfectly acceptable for that teacher, even if his/her beliefs were biblical literalism, to make these known. The beliefs of all the science staff are unknown, but one member of staff, the Head of Science, Stephen Layfield, has made his position clear in public.

In a lecture given at Emmanuel College on 21 September 2001 on the teaching of science from a biblical perspective, Layfield, was quoted as saying:

Those of us engaged in the struggle to show the superiority of a creationist world-view against the prevailing orthodoxy of atheistic materialism and evolutionism in science have been viciously attacked. (Teachers)...must be prepared to express without compromise the integrity and infallibility of the biblical historical narrative. (Anon 2002)

A belief in 6-day creationism by staff at the school runs wider than just the Head of Science. Its first principal, Nigel McQuoid (now Director of Schools at The ESF), in a national Channel 4 television program broadcast on 9 March 2006, Dispatches: The new fundamentalists, admitted to a belief in 6-day creationism. The issue of creationist teaching is also addressed on the Foundation's website:

Creation and the existence of a Creator is naturally presented as a core belief within Christianity, Judaism and Islam. As such it is a key element in the teaching of RE (Religious Education). Naturally, there are points at which these two concepts 'touch' each other; some would say, they collide and both cannot be 'true'. Others believe that they can be compatible. This interface is therefore also embraced, most within RE but, as appropriate to the teaching of the reasons behind certain scientific controversies, within Science also." (http://www.emma nuelctc.org.uk/thefoundation/history/ accessed 24th October 2007)

This position statement implies that whereas creationist teaching is neither required nor an official part of the school curriculum, teaching aspects of creationism may occur as a consequence of the nature of the concept of creation and life's origins, which may arise in religious education and/or science lessons.
What is not in dispute is the Christian ethos by which the college is run.

\section{Reactions from the Scientific, Religious, and Secular Communities}

The idea of creationist teaching in the science lessons of state-funded schools elicited strong reactions from leading scientists and clerics such as Professor Richard Dawkins, Professor Steve Jones, and the Bishop of Oxford, Richard Harries. A letter drafted by the Bishop of Oxford and signed by 43 scientists and religious leaders stated that:

Scientists may disagree about the details and processes of evolution, but they do not disagree about whether it happened, and it is disingenuous of teachers to claim otherwise. We urgently call for: a tightening up of the legal requirements in National Curriculum Science to prevent creation stories being taught as anything other than religious myths; clear guidance from GCSE examination boards to teachers and pupils that creationism is not a scientific hypothesis" (Dawkins 2006:398)

Various groups including the British Humanist Association and the National Secular Society all condemned the possibility of teaching creationism in science lessons. By 2006, the Royal Society was drawn into the argument, issued a statement (Royal Society 2006) and hosted a public lecture by the geneticist Professor Steve Jones (Jones 2006). The lecture generated huge public interest with many people turned away at the Royal Society doors as the lecture theater quickly filled to capacity.

In November 2006, Richard Dawkins, author of The God Delusion, established the Richard Dawkins Foundation. One of its reported aims is "to keep God out of the classroom and prevent "pseudo-science" taking over in schools" (Smith 2006).

\section{Truth in Science}

In September 2006, a new pressure organization, Truth in Science, came to prominence when it distributed to all secondary schools in the UK materials that promoted Intelligent Design as a scientific, viable, alternative explanation of the evidence for the origin and development of life on Earth (Morgan and Taher 2006). The Directors of the organization include Professor Andy McIntosh, professor of thermodynamics at Leeds University, and Willis B. Metcalfe, an evangelical Christian publisher. The origins of Truth in Science are a little unclear, but references to a "new" organization to promote intelligent design in science 
teaching go back to 2004 (BCSE 2007) when a Northern Ireland Evangelical Ministry reprinted a notice from the Evangelical Times (a monthly evangelical newspaper, which lists Metcalfe as a trustee) announcing a meeting of a new organization, Truth in Science. Although the organization maintains it has a nonreligious stance, investigations by a small, independent organization, the British Centre for Science Education (BCSE 2007), allege clear religious links. Quoting from an original Evangelical Times announcement, BCSE sought to expose the religious intent of Truth in Science:

It is a concern to many when science is wrongly taught in our schools, colleges and universities. In particular, macroevolution is taught as though it were a proven and unchallengeable fact. For our children and grandchildren, God is thus robbed of His glory. Young people are encouraged into a way of thinking that leads to atheism, hedonism, despair and moral bankruptcy. Belief in a Creator is often ridiculed and anyone advocating such a view is portrayed as either foolish or naïve.(BCSE 2007)

\section{And}

To respond to this a group of professional and business people are meeting under the heading TRUTH IN SCIENCE [TIS]. As citizens with a concern for the family we seek to encourage Christians to be confident that God's spoken command in space-time history resulted in supra-natural creation. Non-believers must be challenged in such a way that they can no longer hide behind the delusion that science has disproved the existence of God. TIS seeks to encourage scientists to present the truth fairly and to expose as charlatans those who deliberately mislead. Our aim is to compliment the work of existing Creation groups by targeting education in particular.(BCSE 2007)

Originally, Stephen Layfield was listed as a director of Truth in Science, but under pressure from Sir Peter Vardy he resigned his position late in 2006, as the issue of whether or not creationism is taught at Emmanuel College hit the newspaper headlines again (Marley 2006; Paton 2006a, b).

The Truth in Science website features various sections, including reviews of school textbooks and critiques of their approach to evolution and a series of downloadable science lessons, some of which have creationist overtones. The organization is at pains to point out that it is not promoting creationism:

Truth in Science is seeking to encourage the teaching of intelligent design, not Creationism, in science classes. Our packs discuss intelligent design, and not Creationism" (http://www.truthinscience.org.uk/site/ content/view/43/92/ (accessed July 2007) )
The materials distributed to all state secondary schools included two DVDs produced by Illustra Media, Unlocking the Mystery of Life and Where Does the Evidence Lead? with contributions from leading Discovery Institute members. In addition, a small teachers' manual suggests specific learning outcomes for pupils. Teachers are also directed to the Truth in Science website for further resources and lesson ideas. How many schools use the materials and in what way they are used are unknown at present, although Truth in Science claims a very small number of responses (fewer than 100), indicating that teachers are using their materials (http://www.truthinscience.org.uk/site/content/ view/43/92/ (accessed July 2007) ).

Whereas the organization may claim that creationism is not discussed, the web links section has a group of links for creation websites and references to "baraminology", the study of the "created kinds", in its articles and materials. It also links to the Baraminology Study Group, devoted to promoting a young-earth creation model of biological origins (weblink http://www.truthinscience.org.uk/site/component/ option,com_weblinks/catid,14/Itemid,23/). Creationism may not be an overt part of the work of Truth in Science, but it is implicit in its promotional DVDs and resources. Established organizations such as the British Humanist Association and Ekklesia $^{5}$, a theological think-tank, have also condemned the distribution of the materials by Truth in Science.

\section{The Government Position}

The revelation of possible creationist teaching in science lessons at The Emmanuel College Gateshead led to questions being asked in the House of Commons in 2002 (Hansard 2002) through to the House of Lords in 2005 (Lords Hansard 2005). In March 2006, it was found that one national public syllabus for a $\mathrm{GCSE}^{6}$ science examination included reference to creationism (Paton 2006a, b).

\footnotetext{
${ }^{4}$ Baraminology is not a recognized scientific study. The term is derived from the Hebrew bara (created) and min (kind) and was a term coined in 1941 by Frank Lewis Marsh, one of the founders of the creation research society.

${ }^{5}$ The British Humanist Association issued a press release condemning the Truth in Science distribution of materials and wrote to the then Secretary of State for Education asking for a statement from him against the use of the materials in science lessons. Ekklesia, a theological think-tank, also issued a press release condemning the distribution of the materials.

${ }^{6}$ In England and Wales, all students take national public examinations at the age of 16, the General Certificate in Secondary Education (GCSE); these examinations are one of the measures of success by which all state schools and many private schools are measured. All pupils are required to follow courses of instruction leading to GCSE examinations (normally 10), the core subjects of English, mathematics, and science are statutory subjects.
} 
Once more the national press highlighted the creationism/evolution issue, which led this time to a more definitive statement from the then Schools' Minister Jacquie Smith MP, brought on by a campaign from the British Humanist Association to ban creationism from the science classroom:

'controvers[ies]' that could be taught in science lessons are scientific ones...Creationism cannot be used as an example of a scientific controversy, as it has no empirical evidence to support it and no underpinning scientific principles or explanations...Intelligent Design is sometimes erroneously advanced as a scientific theory but it has no underpinning scientific principles or explanations supporting it and is not accepted by the international scientific community. (British Humanist Association 2006)

In an extensive interview for the science magazine New Scientist, in November 2006, Tony Blair was quoted as saying: "If I notice creationism become the mainstream of the education system in this country then that's the time to start worrying." (Webb 2006). He again stated that claims of creationist teaching in schools were "exaggerated". Despite the definitive statement from his own Minister for Schools some months earlier, he did not categorically rule out the teaching of creationism in school science, a move that would have added considerable weight to the publicly stated government position. Why Mr Blair did not take a more definite stance ruling out creationism and supporting his own schools' minister's advice is still unclear.

During this spell of national attention, the Archbishop of Canterbury, Rowan Williams, entered the debate and rejected the teaching of creationism in schools:

I think creationism is ... a kind of category mistake, as if the Bible were a theory like other theories ... if creationism is presented as a stark alternative theory alongside other theories I think there's just been a jarring of categories ... My worry is creationism can end up reducing the doctrine of creation rather than enhancing it, (Bates 2006:1).

\section{Student Views on Creationism}

Empirical studies of student views on creationism and evolution are few in number, but attitudinal surveys conducted in the late 1980s and 1990s by Fulljames and his coworkers (Fulljames and Francis 1987; Fulljames et al. 1991; Francis et al. 1990; Egan and Francis 1992; Fulljames 1996) do provide evidence of what students in schools think. Fulljames studied the attitudinal relationships toward science and religion and of what he terms "scientism" - the idea that scientific theories can reveal absolute truth - and "creation- ism"- defined by him as a literal account of the origins of life as described in Genesis with an acknowledgement that evolutionary theory is false (Fulljames and Francis 1987). Fulljames argues that "creationism" should be distinguished from belief in God as the creator, as "...many Christians from diverse theological standpoints claim that belief in God as creator is consistent with an evolutionary theory of origins." (Fulljames et al. 1991:173).

In a study of 729 16- to 18-year-old students in Scotland, Fulljames (Fulljames et al. 1991) documented a separation of positive Christian attitudes into two forms; the first being one where Christianity necessarily involves creationism, and the other where Christianity did not. For students who held the former position, a positive attitude to Christianity revealed a negative attitude to science. A much larger study (Francis et al. 1990), involving 6,095 students aged 11-15, again from Scotland, further confirmed the difficulty that students have in holding positive attitudes toward science and Christianity where creationism is a necessary part of the Christian belief. Further analysis of these data showed that the students' views changed with age. Older students (aged 15-16) developed a more negative attitude toward Christianity. This finding is supported by Egan and Francis (1992), who concluded that: "while creationism commends the gospel among 11-13 year olds, it detracts from the gospel among 16-17 year olds." They continue by sounding a warning that the teaching of creationism in schools may be "counter productive to the church's mission" (Egan and Francis 1992:27). In a further study conducted on 3,427 11- to 15-year-old students in England (Fulljames 1996), Fulljames controlled for creationist beliefs and found that where students have a view of Christianity as necessarily involving creationism, there was a negative attitude toward Christianity where creationism was not a necessary part of the belief system.

The main problem with Fulljames' approach, as discussed by Francis and Greer (Francis and Greer 2001:42), was a lack of rigor in determining the student's views on science, resulting in conclusions being drawn on the basis of only one or two survey items. Francis and Greer adapted the surveys to look at adolescent attitudes toward science and religion in Northern Ireland, obtaining completed questionnaires from 1,584 14- to 16-year-old pupils (Francis and Greer 2001). Northern Ireland is distinctive in the UK as a division between Catholic and Protestant schools affords interesting insight from two Christian perspectives. The data were analyzed using a variety of indicators including sex, age, personal prayer habits, church attendance, number of sciences studied, attitude toward scientism and creationism. The findings from this survey showed that, in general, differences in scientism could not be predicted from knowledge of any of the factors listed above, barring personal prayer, which showed a negative 
correlation. Differences in creationism, however, could be predicted by sex, school type, age, prayer, and church attendance. The authors concluded that being a young, female, devout, church attendee at a protestant school all led to higher levels of belief in creationism. They sound a warning here for science educators:

From the perspective of evangelical churches, it is clear that science education is doing nothing to undermine conservative evangelical belief. From the perspective of science educators, it is equally clear that science education is doing nothing to enhance the credibility of evolutionary theory among conservative Christian believers (Francis and Greer 2001:48-49)

A difference in attitude could also be predicted from knowledge of all but personal prayer and church attendance, with young males attending a protestant school studying more than one science being associated with a positive attitude toward science.

Attitudes to Christianity could also be predicted by all of the factors apart from the number of sciences being studied. The study showed that attitudes toward Christianity decline with age, with young female, church going Catholic's being most positive toward Christianity. The authors conclude that "studying science does no harm per se to the development of a positive attitude towards Christianity" (Francis and Greer 2001:50).

The study also found that creationist belief was a significant factor across the age group, with this positively correlating with a Christian attitude and with a less favorable attitude toward science. They note here the challenge for science educators and religious educators, namely, the dismantling of creationist beliefs to promote positive attitudes toward science. Another significant factor was scientism, with a positive attitude to scientism leading to a less favorable attitude to Christianity.

To promote a positive attitude toward science and Christianity, the authors suggest that students should be equipped with:

...an understanding of the nature of science which questions the claims of scientism and an understanding of the Christian faith which questions the literal authority of the Genesis creation narratives. Both positions being highly consistent with accepted trends within the philosophy of science and within the critical traditions of

Christian theology (Francis and Greer 2001:50-51)

The studies described have been initiated from the perspective of attitudes toward religion rather than being driven by a study of attitudes toward science, but they necessarily reveal interesting data on the attitudes toward science and creationism, which prevail in UK school age students.

Attitudinal studies on the views of teachers and managers in schools are not evident in published studies and the research literature, but a national poll of the general public's attitude toward creationism and evolution was conducted by the BBC science programme Horizon in January 2006. This poll revealed that, when asked to describe the position that best reflected their views on the origin of life, $22 \%$ chose creationism, $17 \%$ opted for intelligent design, $48 \%$ selected evolution theory, and the remaining $13 \%$ were unsure.

When asked which of these positions (respondents could choose more than one position) they would like taught in science classes, $44 \%$ said creationism should be included, $41 \%$ wanted intelligent design, but $69 \%$ wanted evolution as part of the science curriculum (BBC 2006).

\section{Evolution in School Textbooks}

A popular high school biology textbook from the 1950s boldly declares that "In this book, it is assumed that the reader believes in the existence of God, and accepts the logical consequences of the fact" (Grogan 1955:vii). The author, John Grogan, was a senior science master at Thornleigh College, Bolton, founded in 1925 by the Catholic Salesian Society. The book does not, however, avoid the issue of evolution and devotes 25 pages to the description and discussion of evolution, including evidence for the fact of evolution. Where the origin and diversity of species is concerned, Grogan writes "If the task of filling the world with creatures had been given to human beings, they would most likely have started with a few kinds and gradually modified them in different ways" (Grogan 1955:284), supporting the view of a gradualistic model for evolution as proposed by Darwin in The Origin of Species. There is also a warning delivered by Grogan, that what we may perceive as common sense does not necessarily reflect the mind of God: "What we must do is examine the evidence and try to find out what God did-not what we think he should have done." (Grogan 1955:284)

A new edition of the book, revised in 1963 by Sister Marie Josephine, a lecturer in the Catholic Notre Dame College of Education, Glasgow, Scotland, removed the quotation on the assumption of a belief in God and removed reference to trying to understand the mind of God. But it still contained a clear creation doctrine by stating that whereas evolution may account for the development of the body "...the formation of the soul is an act of special creation" (Grogan 1963:300).

Over the next 20 years or so textbooks concentrated on the facts of science and references to belief in God were absent from the introductions and text. The coverage of evolution as a topic became general and somewhat entrenched in references to Darwin's finches, the evolution of the horse, the Miller-Urey experiment, and the occurrence of the peppered moth. To this day, these same "examples of evolution" proliferate (Mackean 2002; Bradfield and Potter 2002; Gadd 2005). It is these self 
same examples that are attacked by creationists such as Jonathan Wells (Wells 2000). Given the advances in understanding how evolution has led to diversification, speciation, and the much fuller, better picture that scientists have now of how macroevolution explains and links major vertebrate groups, the reliance of curriculum developers and textbook writers on older examples is curious. Few textbooks bring in contemporary evidence for macroevolution, although plenty of robust examples exist, e.g., dinosaur to bird evolution, the evolution of the whale and observed speciation, but many textbooks do now include the development of resistance to antibiotics of bacteria and rat resistance to warfarin.

The current textbooks intended for use with pupils aged 14-16 have a positive, scientific attitude to evolution. As teaching about evolution is a statutory requirement, the textbooks reflect this. Schools are free to choose whichever textbook meets their needs. An increasing trend is for textbooks to be linked to individual public examination specifications. As a result, schools often choose the textbook most closely associated with the specification their pupils follow. The overall approach to evolution taken by textbooks is that evolution is an established scientific fact and the theory is supported by evidence from the fossil record and more recent examples such as resistance to antibiotics by some strains of bacteria. As noted earlier, the current move toward teaching science from a process perspective, how science works, should establish that whereas creationism may claim that evolution is "just a theory", in scientific terms a theory is robust, supported by much evidence, and accepted by the scientific community as a whole (Williams 2008).

Few current textbooks in science tackle the issue of creationism head on, although in two instances, in textbooks for students aged 11-14, (Heslop et al. 2005; Petheram 2004) there has been an attempt to preempt the notion of creationism entering the science curriculum. In one textbook, a section on creation myths has activities designed to allow students opportunities to demonstrate the unscientific nature of creation stories (Heslop et al. 2005:4-5). For older students (aged 14-19), textbooks do not tackle creationism, but there is still an overreliance on the "standard" accounts of the evidence for evolution. A legitimate question may be raised here; should science textbooks engage with any form creationism? Given the move toward teaching about the nature of science, it may indeed be legitimate to consider, under the banner of the history of science, ideas that the scientific community once held, which today are not considered scientific, e.g., phogiston theory, Paley's watchmaker or even alchemy. By examining how science rejected these once held "theories", pupils may be equipped with an approach that will enable them to distinguish real science (evolution) from pseudoscience (creationism/intelligent design).

\section{The Teaching of "Origins" in Religious Education}

Until the introduction of the national curriculum 1988, the only subject that was required by law to be taught in schools was religious education. To this day, religious education is a statutory requirement for all UK state schools, but the nature and character of the subject has changed considerably from its earlier days of biblical teachings to a more comprehensive knowledge and understanding of the world's major faiths. Schools and teachers in England and Wales have, for guidance, centrally produced schemes of work that exemplify how the national curriculum subjects could be taught (QCA 2007). In the case of religious education, one unit of work, designed to be used with students aged 13-14, considers the question of "origins" (QCA). Here teachers and students have an opportunity to address questions at the heart of the issue of creationism, evolution, and origins:

\section{Children should learn:}

\section{about the scientific theories of the Big Bang and evolution}

about the story in Genesis 1-3

to understand the meaning and significance of the story to religious believers

to understand the terms theistic evolution and creationism to explain questions of meaning and purpose (QCA:3)

The national schemes of work are merely one example of how the statutory national curriculum may be delivered in state schools. Although the content of the national curriculum and religious education are required by law to be taught, the exemplar schemes of work do not have any statutory status, and schools and teachers are free to use, adapt, or ignore them. If they choose to ignore the exemplar schemes, they must still deliver the statutory content by devising their own schemes of work. Regular inspections of state schools check on whether the statutory content of the curriculum is being adequately delivered. It is interesting to note, however, that although there is a place in all state schools to explore the creationism - science schism, in the religious education classroom, pressure is still being applied for the inclusion of intelligent design creationism in science lessons.

\section{Summary}

Controversy and debate on the issue of creationism has, for many years, been low key in the UK. This may, in part, be caused by the inclusion of religious education in all state schooling a situation that those who wish to promote a 
nonsecular education welcome. Calls for a secular education in the UK have been made, most notably by Dawkins (Dawkins 2006; Smith 2006).

The extent to which creationist teaching is a reality in UK schools has little to no empirical evidence one way or the other. The scientific establishment and the government have rejected creationism and intelligent design and reject calls for their inclusion in the school science curriculum as a viable alternative to Darwinian evolution. The Church of England's highest authority, the Archbishop of Canterbury, also rejects the teaching of creationism in schools adding that this may be more harmful than helpful. In its proper place, the religious education curriculum, there is provision for the study of the more philosophical questions humanity has about its origins and the perceived conflict between science and religion.

Studies reveal that students have an increasingly negative attitude toward creationism with age, but that younger groups aged between 11 and 14 are more inclined to accept creationism as the "true" explanation for human origins and development. They also show that studying science does not in itself necessarily lead to a more negative attitude toward Christianity.

The studies also highlighted the need for better teaching about the nature of science and a better understanding of the Christian faith and its questioning of the literal authority of Genesis.

The commonly used science textbooks may be overreliant on "standard" examples of the evidence for evolution (e.g., the evolution of the horse) and are lacking in more robust contemporary examples, such as the evolution of the whale.

\section{Implications}

Four main implications are apparent from this review of creationism in UK schools;

1. More research is needed on the extent of creationist teaching in UK schools and on the attitudes of teachers and school managers to the evolution/creationism/ intelligent design issue.

2. Further work on students' attitudes toward evolution and creationism - extending this to the relatively new area of intelligent design creationism-is needed to ascertain what impact these may have on attitudes toward science, Christianity, or any of the major world religions represented in UK society. This work may also provide insights into the poor uptake of study in the sciences by students entering university, at present a national concern in the UK.

3. Whereas the new science curriculum for school students concentrates on the process of science or "how science works", there is evidence to suggest that science teachers' own understanding of the process of science and the status of a theory, fact, and law in science is not fully developed. This requires development in the form of curriculum materials and in service training for science teachers so that they are clear about the nature of science and how this impacts on their teaching approach. More research is needed on what pupils and teachers understand by the terms, theory, fact, and law in science.

4. Curriculum developers and textbook writers urgently need to incorporate newer, more robust examples of macroevolution and common descent, from a variety of scientific disciplines, including relationships between present and past groups such as dinosaurs and birds and the evolution of whales, as well as examples of speciation. This should also include information on the range of transition fossils we have to support macroevolution and common descent.

By taking on board these implications and acting to ensure that the controversy over evolution we discuss in science classes are the true controversies in evolution, such as neutralism versus selectionism in molecular evolution; adaptationism; group selection; punctuated equilibrium versus phyletic gradualism; the nature of the Cambrian Explosion; the causes of mass extinctions, etc., we can ensure that any fear of creationism or intelligent design becoming a part of mainstream education is never realized.

\section{References}

Allgaier J, Holliman R. The emergence of the controversy around the theory of evolution and creationism in UK newspaper reports. Curric J 2006;17:263-279.

Anon. The Bible versus Science Guardian. http://www.guardian.co.uk/ religion/Story/0,2763,664607,00.html (accessed June 2007). 2002

Bates S. Archbishop: stop teaching creationism. Guardian, 21 March 2006

BBC. Horizon: a war on science. Broadcast, 26 January 2006

BCSE. The strange practice of take heed ministries BCSE website. http://bcseweb.org.uk/index.php/Main/TakeHeedMinistries (accessed July 2007). 2007

Bradfield P, Potter S. Longman GCSE Biology, Longman: Harlow. 2002

Branigan T. Top school's creationists preach value of biblical story: state-funded secondary teachers do not accept findings of Darwin. Guardian, March 9. 2002

British Humanist Association. Creationism and ID not science, cannot be taught in science. http://www.humanism.org.uk/site/cms/ newsarticleview.asp?article=2175 (accessed May 2007). 2006

Dawkins R. The God delusion. 1st ed. London: Bantam Press; 2006.

DfEE. Science: the national curriculum. London: The Stationary Office; 1999.

Egan J, Francis L. Does creationism commend the gospel? A developmental study among 11-17 year olds. Relig Educ 1992; 87:19-27.

Francis LJ, Greer JE. Shaping adolescents' attitudes towards science and religion in Northern Ireland: the role of scientism, creationism and denominational schools. Res Sci Technol Educ 2001; 19:39-53. 
Francis LJ, Gibson HM, Fulljames P. Attitude towards Christianity, creationism, scientism and interest among 11-15 year olds. Br J Relig Educ 1990; 13:4-17.

Fulljames P, Francis LJ. Creationism and student attitudes towards science and Christianity. Journal of Christian Education 1987; 90:51-55.

Fulljames P. Science creation and christianity: a further look. In: Francis LJ, Kay WK, Campbell WS editors. Research in religious education. Gracewing, Leominster; 1996. pp. 257-266.

Fulljames P, Gibson HM, Francis LJ. Creation, scientism, christianity and science: a study in adolescent attitudes. Br Educ Res J 1991;17:171-90.

Gadd K (ed). AQA GCSE Science. 1st ed. London: Harper Collins; 2005.

Grogan J. The living world. London: John Murray; 1955.

Grogan J. The living world, revised edition. John Murray: London; 1963. p. 300

Hansard. Jenny Tonge MP http://www.publications.parliament.uk/pa/ cm200102/cmhansrd/vo020313/debtext/20313-03.htm\#2031303 spmin22 (accessed May 2007). 2002

Heslop N, Brodie D, Williams J. Hodder science: platinum first edition. London: Hodder Murray; 2005.

Hoggart S. In the beginning was the word... happiness. Guardian, March 14. 2002

Jones S. Why creationism is wrong and evolution is right. Royal Society Public Lecture 1 April available at: http://www.royalsoc. ac.uk/page.asp?tip=1\&id=4400 (accessed May 2007). 2006

Lords Hansard. Lord Filkin. http://www.publications.parliament.uk/pa/ ld200405/ldhansrd/vo050131/text/50131-01.htm\#50131- 01_spopq1 (accessed May 2007). 2005

Marley D. Creationism tag puts academies at risk, says Vardy. Times Educ Suppl, 24 Nov. 2006.

Mackean DG. GCSE biology, 3rd ed. London: John Murray; 2002.

Morgan C, Taher A. Creationism gains foothold in schools, The Sunday Times: December 31, 2006 http://www.timesonline.co. $\mathrm{uk} /$ tol/newspapers/sunday_times/britain/article1265412.ece
Paton G. How Genesis crept back into the classroom . Telegraph, 28 November. 2006a

Paton G. When is a fossil not really so old? Times Educational Supplement:1. 2006b

Petheram L. Scientifica: Time surfers, 1st ed. Cheltenham: Nelson Thornes; 2004

QCA. National schemes of work for national curriculum subjects. http://www.standards.dfes.gov.uk/schemes3/?view=get (accessed June 2007)

QCA. Unit 9B: Where did the universe come from? London: HMSO.

Royal Society. Royal Society statement on evolution, creationism and intelligent design. http://www.royalsoc.ac.uk/news.asp?id=4298 (accessed June 2007). 2006

Smith A. Dawkins campaigns to keep God out of the classroom, Guardian, November 27, 2006. http://education.guardian.co.uk/ schools/story/0,,1958138,00.html accessed 24 October 2007. 2006

Vardy P. BBC Radio 4: Today Program Interview Broadcast, 28th April (a transcript of this interview is available at http://www.angelfire. $\mathrm{com} / \mathrm{nb} / \mathrm{lt} /$ docs/called43.htm (accessed June 2007)). 2003

Vardy P. BBC Radio 4: Today Program Interview Broadcast, 15 April. http://www.bbc.co.uk/radio4/today/listenagain/ram/ today2_academy_schools_20060415.ram. 2006

Webb J. Interview: Tony Blair on Science new scientist, 1 November. Full transcript/recording available at http://www.newscientist. com/channel/opinion/dn10422-tony- blair-interview-in-full.html (accessed May 2007). 2006

Wells J. Icons of evolution, 1st ed. Washington: Regnery Publishing; 2000.

Williams J. So just how does science work? In: Burton, N. editor. PGCE trainee perceptions of the scientific method. Hatfield: ATSE Annual Conference Proceedings ASE; 2006.

Williams J. The scientific method and school science. J Coll Sci Teach 2008 (in press). 